\title{
Veelfasettige rekonstruksie van 'n ontglippende persoonlikheid
}

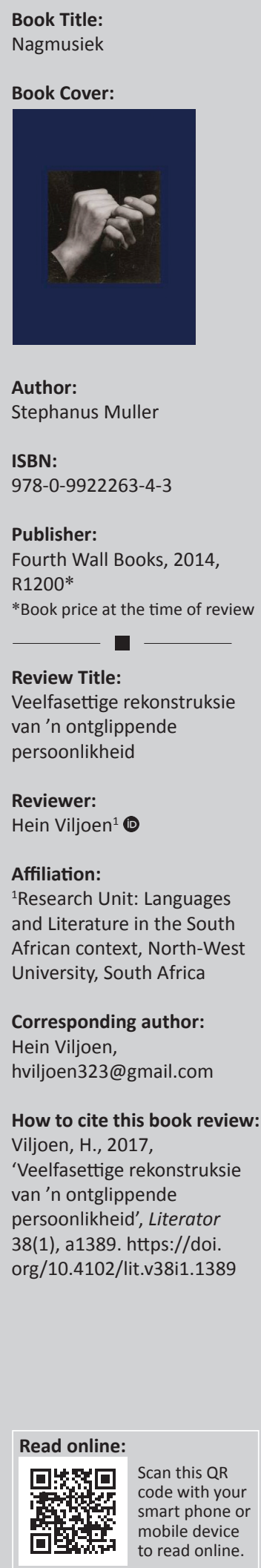

Nagmusiek is Stephanus Muller se eksperimentele biografie van die komponis Arnold (Nols) van Wyk. In plaas daarvan om 'n deurlopende narratief van Van Wyk se lewe te skryf, problematiseer Muller die sogenaamde biografiese 'feite' en skep daardeur ruimte vir bespiegeling oor en rondom die figuur van Nols. Muller se kernkunsgreep is dat hy 'n fiktiewe teenhanger van homself (en van Van Wyk) as biograaf skep: die neurotiese pedant Werner Ansbach, in wie se gedagtes die worsteling met die oorgelewerde feite en dokumente van Arnold van Wyk dan geprojekteer word. Hy skep ook 'n ironiese teenhanger vir hierdie postmoderne twyfelende biograaf, naamlik die figuur van die Groot Biograaf - seker van sy feite, baie produktief, vol selfvertroue.

Kernkwessies wat in die boek getematiseer word, is die aard en waarde van sg. biografiese feite, die vraag met wie se stem die biograaf nou eintlik praat en die vraag waar en hoe die subjek se verhaal begin en hoe (veral in watter volgorde) dit vertel moet word. Oor die boek hang ook twee baie groot hermeneutiese vrae, naamlik hoe Van Wyk se werk in'n postkoloniale (dekoloniserende) situasie verstaan moet word en watter nut die skryf van sy biografie, en dit nogal in Afrikaans, vir die internasionale verstaan en waardering van Van Wyk se werk sou hê.

Die kwessie van stem word sterk vooropgestel. Naas die stem van Ansbach, word Van Wyk se eie stem via sy briewe en kommentare gehoor, en ook die stemme van Van Wyk se vriende en kollegas deur hulle briewe, maar ook uit onderhoude met hulle. Daar is boeiende onsekerheid oor die stem wat aan die woord is en in watter mate die stemme dan almal plaasvervangers vir Muller, die biograaf, of blote spreekbuise van Van Wyk self is. Immers, van Muller se akademiese referate word in die mond van Ansbach gelê en Ansbach praat in sy gesprekke met Cecile vir Van Wyk na. Amper soos Multatuli vir Droogstoppel wegstuur, laat Muller aan die einde van die boek sy spreekbuis, Ansbach, oënskynlik selfmoord pleeg en beëindig daarmee sy eksperiment met die vertellerstem.

Een van die kernvrae in die boek is juis hoe 'n ontglippende subjek uit al die dokumente en spore van sy bestaan vasgevang kan word. Muller (of dan Ansbach) belig sy subjek uit verskillende hoeke, soos o.m. blyk uit die drie dele waaruit die boek bestaan. Deel 1 is 'n noukeurige katalogus van al Van Wyk se komposisies. Deel 2 bevat die voetnote vir die derde deel, wat dan bestaan uit Ansbach se metanarratief van die skryfproses, aangevul deur gedetailleerde verslae van episodes uit Van Wyk se lewe, met foto's en afbeeldings van die dokumente (wat egter sonder byskrifte geplaas word sodat die leser sy eie byskrifte moet bedink).

Die narratief word gefragmenteerd en sonder 'n liniêre chronologie aangebied. Maar in die loop van die teks, gee die outeur wel aan die lesers drie stelle vaskloupunte: drie chronologieë waardeur hulle wel 'n effense greep op die werk kan kry. Die eerste chronologie handel oor die lewe van Van Wyk, die tweede is 'n chronologiese verslag van sy komposisies, uitvoerings en musikale voor- en afkeure en die derde karteer die lewens van die mense wat 'n belangrike rol in Van Wyk se lewe gespeel het. Tussendeur plaas Muller ook drie belangrike essays deur homself, wat hy ook in die mond van Ansbach lê. Hierin artikuleer hy sy siening, sy dit dan indirek en voorlopig, van Van Wyk se musikale oortuigings en opvattings.

Ander vaste punte wat die skrywer vir die leser bied, is die sirkulerende motiewe in die boek. 'n Opvallende motief is Ansbach se verbete, maar absurde stryd teen die molle wat sy grasperkie ondermyn (net soos hy amper ondergronds in die argiewe delf). Ewe opvallend is die motief van Van Wyk se homoseksualiteit (wat ook 'n absurde teenhanger het in Ansbach se ontmoetings met Cecile). Meesleurend en ontroerend is egter die deurlopende motief van Nols se hande. Dat 'n foto van Van Wyk se hande ook aangebring is op die foedraal (kassie) waarin die drie dele bymekaargehou word, onderstreep die belang van hierdie hande.

Copyright: @ 2017. The Authors. Licensee: AOSIS. This work is licensed under the Creative Commons Attribution License. 
Alhoewel daar dus twyfel geskep word in die biografiese feite (of eerder, die inherente onvastigheid van die biografiese feite aangetoon word), word die feite andersyds uit verskillende hoeke aangevul en gekontrasteer met die presieuse lewe van Werner Ansbach, wat soms, en veral dan in die musikologiese diskussies met sy urine-seksueel geobsedeerde student, Cecile, letterlik Van Wyk se woorde in sy mond neem; as afsplitsing van 'Nols' self funksioneer.

Die resultaat van hierdie veelfasettige benadering is, ironies genoeg, nie om Van Wyk as biografiese subjek in alle besonderhede vas te vang nie, maar om 'n ryk geskakeerde weefsel van feite (en soms ook spekulasies) tot stand te bring waaragter die leser Van Wyk as mens op 'n tergend ontglippende wyse kan raaksien, maar waaruit sy wese as't ware tussen sluiers deur weer ontsnap. Die versigtige, huiwerige omgaan met die feite toon aan hoe moeilik vasstelbaar hulle is en hoe weinig die vasstelbare feite uiteindelik van die subjek sê.

Nagmusiek is as wenner aangewys van sowel die kykNETRapport Boekprys vir niefiksie en die Jan Rabie-Rapportprys vir debuutwerk in 2015. In sy commendatio vir die Jan RabieRapportprys het Thys Human die boek beskryf as:

tegelyk 'n outobiografie (van die fiktiewe outeur Werner Ansbach), 'n biografie (van die gekwelde, maar uiters talentvolle komponis, Arnold 'Nolsie' van Wyk), 'n metafiksionele ondermyning van die hele projek van biografieskrywing en egodokumentasie, maar óók 'n volledig (uitgestelde) roman waarin die skrywer hom van 'n hele arsenaal van literêre middele bedien. (Human 2015)

Nagmusiek is in Mei 2015 reeds bekroon met die UJdebuutprys vir Skeppende Skryfwerk in Afrikaans. Ronel Johl het die boek in haar commendatio geprys as 'n groot werk: "n hibriede-teks wat tegelyk 'n geslaagde biografie en selfbeskouende fiksie/"outobiografie" en vernuwende musiekkunde is (in Afrikaans, nogal), 'n boek wat 'n uiteenlopende leserspubliek op verskeie maniere uitdaag' (Botha 2015).

Die eindresultaat van die biografiese en literêre arbeid van die skrywer is boeiend en ontroerend. Nagmusiek is ' $\mathrm{n}$ tour de force wat dalk, juis deur die onvastheid en onsekerheid daarvan, iets van die romantiese gees van Van Wyk vasvang - die ewig verlangende, die ewig gekwelde, ewig strewende romantiese kunstenaar, ewig aan die stoei om iets geskryf te kry, nooit tevrede met wat hy geskryf het nie.

\section{Literatuurverwysings}

Botha, Frederick J., 2015, 'Soms is die waarheid oor 'n lewe meer storie as feit' besigtig op 26 Mei 2017, vanaf Sunday Times Books LIVE, http://bookslive.co.za/ blog/2015/05/13/2015-uj-pryse-soms-is-die-waarheid-oor-n-lewe-meer-storieas-feit/

Human, Thys, 2015, 'Commendatio: Jan Rabie-Rapportprys 2015,' besigtig op 20 November 2016, vanaf Sunday Times Books LIVE, http://bookslive.co.za/ blog/2015/11/20/hoe-kon-nagmusiek-deur-stephanus-muller-vir-beide-fiksieen-niefiksie-boekpryse-wen/ 